\title{
Electrical System Design of Solar-Powered Electrical Water Recreational and Sport Vessel
}

\author{
Sunaryo ${ }^{*}$ and Pradhana Shadu Imfianto \\ Naval Architecture and Marine Engineering Study Program, Department of Mechanical Engineering, \\ Universitas Indonesia, Depok 16424 Indonesia
}

\begin{abstract}
Indonesia is the world's largest archipelago with more than 17000 islands, and the best marine tourism destination due to its beautiful beaches and underwater scenery, but Indonesia is also the most vulnerable country to be affected by climate change due to the greenhouse effect. Besides industry, the transportation sector is the highest contributor to the global greenhouse effect. In order to reduce the source of the greenhouse effect, the Indonesian Government has committed to using new and renewable energy as an alternative to fossil-based fuel. In an attempt to contribute to the Government's efforts and to advance the national marine tourism, the research is aimed to design water recreational and sport vessel that powered by a solar generated electric engine, as further development of Universitas Indonesia's solar boat participated in International Solarboat Challenge competition in the Netherlands. The research is focused on the effective use of solar energy as the main source for powering the vessel's electrical engine, based on the existing optimum shape and dimensions of the boat. Information and data regarding the arrangement of the vessel, solar electric generation processes and vessel powering system obtained from literature study, discussion with experts, and on the spot surveys of various recreational vessels were used as input for the calculation and simulation of the vessel being investigated. The research results are expected could be further developed for other related usages such as fish farming, coastal fishing rig, floating restaurant, etc.
\end{abstract}

Key words: Boat, electric propulsion, renewable energy, semi-trimaran

\section{Introduction}

In recent years, Indonesia has emerged as one of the most favorite tourist destinations. With this positive growth from the tourism aspect, the potential development of a water vehicle that works on clean energy also emerged. This demand arises as to the awareness of protecting the environment of tourism spot become major issues in a certain area of the world, especially Indonesia [1]. The possibility of using solar energy as the sole power source to a vessel is a perfect solution to solve this issue. In recent years, several boat building and renewable energy companies have launched their solar boat products, companies such as Planet Solar [2], Azura Marine [3] and SoelCat [4] have initiated the development of solar boat as water vehicle which able to operate at tourism spot without polluting the environment [5]. This condition opened the possibility to bring solar boat

\footnotetext{
*Corresponding author: naryo@eng.ui.ac.id
} 
technology into personal water vehicle/sports water vehicle application. In order to respond to that condition, this paper proposes a base design of a personal solar electric boat that is projected to replace small watercraft vehicles such as jet-ski or motorized kayak. This proposed design will be a proper reference in designing a solar electric boat which its application range would vary from personal watercraft up to big passenger vessel.

\section{Methodology}

The design of the solar-powered boat will be divide into the hull, mechanical, and electrical aspects. The dimension of the boat and its technical specification are limited to Dutch solar challenge 2016 rules and regulations [6]. In this part of the paper, the writer will be showing the boat dimensions and her technical specification.

\subsection{The boat}

For the project, the boat being proposed is shown in Figure 1, and has the following main particulars:

(i) Semi-Trimaran hull

(ii) Single pilot

(iii) Maximum speed: $20 \mathrm{~km} \mathrm{~h}^{-1}$ to $25 \mathrm{~km} \mathrm{~h}^{-1}$ ( 11 knots)

(iv) Maximum Cruising time: $4 \mathrm{~h}$ to $5 \mathrm{~h}$ continuous operation and depends on sunlight. With optimum cruising time: $2 \mathrm{~h}$ to $3 \mathrm{~h}$.

(v) Length overall: $5.8 \mathrm{~m}$

(vi) Width: $1.8 \mathrm{~m}$

(vii) Draft at full load: $0.124 \mathrm{~m}$

(viii) Weight: $300 \mathrm{Kgs}$

The boat is equipped with one $4.3 \mathrm{~kW}$ pod propulsion system permanent magnet asynchronous motors; cruising speeds equal to $15 \mathrm{~km} \mathrm{~h}^{-1}$ to $20 \mathrm{~km} \mathrm{~h}^{-1}$ ( $\left.\sim 10 \mathrm{knots}\right)$; Average electrical power required during the cruise $4 \mathrm{~kW}$.

Fig. 1 Semi-trimaran hull boat

Trimaran hull is selected in order to get the best power to weight ratio; to ensure proper stability; and space availability for PV panels along with its electrical equipment. Therefore, it is necessary to arrange optimum quantities of PV Panel. 


\subsection{Electrical system}

\subsubsection{Batteries}

It is assumed that the average electrical power needed during the cruise is $3 \mathrm{~kW}$, and the maximum peak power is up to $5 \mathrm{~kW}$ with most of the power will be used for the propulsion system. Since this boat is designed to take the place of normal Jet Ski or other personal small watercraft, its daily operational will be around $2 \mathrm{~h} \mathrm{~d}^{-1}$ to $3 \mathrm{~h} \mathrm{~d}^{-1}$ with the assumption that the boat propulsion system is always running. Also, its maximum weight should be as minimum as possible, as the most electric vehicle has a problem with its weight due to battery pack weight, in this project the use of the available area for the PV Panel and construct small but powerful enough battery pack is maximized.

To minimize the vessel weight, the battery package should be as simple as possible. Therefore, the types of battery that will be used are essential to determine the weight of the package. In this project battery package was custom-made our using 144 cells of Lithiumion Battery, and this battery pack will be monitored with aftermarket BMS (Battery Management System).

Table 1 Battery specification

\begin{tabular}{|l|l|}
\hline Voltage nominal $(\mathrm{Vb})$ & $44.4 \mathrm{~V}$ \\
\hline Normal capacity & $3000 \mathrm{mAh}$ \\
\hline Weight & $10.2 \mathrm{~kg}$ \\
\hline Dimension & $420 \mathrm{~mm} \times 180 \mathrm{~mm} \times 280 \mathrm{~mm}$ \\
\hline Vmax & $50.4 \mathrm{~V}$ \\
\hline Vmin & $33 \mathrm{~V}$ \\
\hline $\begin{array}{l}\text { Max discharge current / solar } \\
\text { charging voltage }\end{array}$ & $150 \mathrm{~A} / 50.4 \mathrm{~V}$ \\
\hline
\end{tabular}

These cells of the battery will be put in one battery box that will be lined up into 12 Series and 11 Parallel sets of batteries. Therefore, this custom made battery will be resulted in this the specifications shown in Table 2 and expressed in Figure 2.

Table 2 Specifications of custom made battery pack LG

\begin{tabular}{|l|l|l|}
\hline Item & Condition / Note & Specification \\
\hline Capacity & Std. Charge / discharge & $3000 \mathrm{mAh}$ \\
\hline Nominal Voltage & Avarage of Std. Discharge & $3.60 \mathrm{~V}$ \\
\hline Continuous discharge current & & $20 \mathrm{~A}$ \\
\hline \multirow{3}{*}{ Standart charge } & Constant current & $1500 \mathrm{~mA}$ \\
\cline { 2 - 3 } & Constant Voltage & $4.20 \mathrm{~V}$ \\
\cline { 2 - 3 } & End current (Cut off) & $50 \mathrm{~mA}$ \\
\hline Fast charge & Constant current & $4000 \mathrm{~mA}$ \\
\hline
\end{tabular}

Table 2 continue to the next page 
Table 2 (Continued).

\begin{tabular}{|l|l|l|}
\hline Item & Condition / Note & Specification \\
\hline \multirow{4}{*}{ Max. charge voltage } & Constant Voltage & $4.20 \mathrm{~V}$ \\
\cline { 2 - 3 } & End current (Cut off) & $100 \mathrm{~mA}$ \\
\hline Max. charge current & & $4.20 \pm 0.05 \mathrm{~V}$ \\
\hline \multirow{3}{*}{ Fast discharge } & & $4000 \mathrm{~mA}$ \\
\hline \multirow{3}{*}{ Max. discharge current } & Constant current & $600 \mathrm{~mA}$ \\
\cline { 2 - 3 } & End Voltage (Cut off) & $2.5 \mathrm{~V}$ \\
\hline Weight & Constant current & $10000 \mathrm{~mA}$ \\
\hline \multirow{3}{*}{ Operating temperature } & End Voltage (Cut off) & $20000 \mathrm{~mA}$ \\
\hline \multirow{3}{*}{ Storage temperature } & Approx. & $20000 \mathrm{~mA}$ \\
\hline & Charge & Max. $47.0 \mathrm{~kg}$ \\
\cline { 2 - 3 } & Discharge & $0{ }^{\circ} \mathrm{C}$ to $50^{\circ} \mathrm{C}$ \\
\hline & $1 \mathrm{mo}$ & $20^{\circ} \mathrm{C}$ to $75^{\circ} \mathrm{C}$ \\
\cline { 2 - 3 } & 3 mo & $20^{\circ} \mathrm{C}$ to $60^{\circ} \mathrm{C}$ \\
\cline { 2 - 3 } & 1 yr & $20^{\circ} \mathrm{C}$ to $45^{\circ} \mathrm{C}$ \\
\hline
\end{tabular}

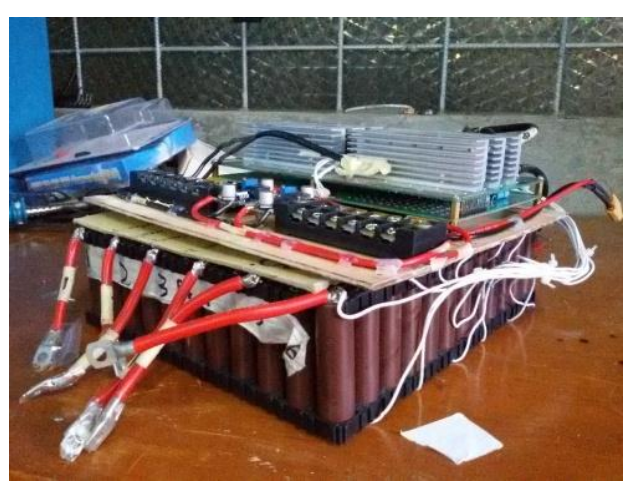

Fig. 2 Custom made a battery pack

In order to guarantee the battery is well protected, this battery pack will be put inside a battery box that also has a cooling system to ensure battery temperature stay under control. In conclusion, a storage system has been built made by 144 cells of batteries into one battery pack, with these features:

(i) Total weight: $10 \mathrm{~kg}$ (battery box included)

(ii) Equipped with cooling system and monitoring system, also safety features that prevent it from electrical failure.

(iii) Volume: $0.420 \times 0.180 \times 0.280 \approx 0.024 \mathrm{~m}^{3}$

(iv) Maximum electrical energy storage $\approx 1.5 \mathrm{kWh}$.

With this compact design of the Battery pack, the overall weight of its electrical storage system does not exceed $15 \mathrm{~kg}$. Which means this boat will be handy and very light on the water. Also, this electrical system minimizes the needs of other mechanical equipment that 
may require additional weight. To activate it connects every electrical device with the cable to battery terminals, such condition also occurs on motor propulsion which only to connect its power distribution system from motor controller to battery terminal, which creates less noise, better efficiency, and reliability.

\subsubsection{Photovoltaic generating system and solar charge controller}

The area available in the boat for laying photovoltaic array is about $15 \mathrm{~m}^{2}$. On this area, it is possible to install four Canadian Solar Polycrystalline $260 \mathrm{Wp}$ solar module; this type of panel has a dimensions of $1.280 \mathrm{~mm} \times 928 \mathrm{~mm} \times 55 \mathrm{~mm}$, each of the panels weighs $20 \mathrm{~kg}$; Maximum Power Voltage $\left(V_{m p}\right) 50.4 \mathrm{~V}$, Maximum Power Current $\left(I_{m p}\right) 5.15 \mathrm{~A}$, which leads to a Maximum Output Power $\left(W_{P \max }\right) 260 \mathrm{~W}$ in Standard Test Conditions. This 4 PV Panel will be connected in separated two series arrangement, then into a parallel arrangement that will be connected into one solar charge controller. The MPPT control technology is widely used in the application of solar power generation. As shown in Figure 2, the output voltage of the photovoltaic array can be determined in such a way that the corresponding power is the maximum out-power. If the working point is on the left of the maximum power point: $\mathrm{d} P / \mathrm{d} V>0$; and if the working point is on the right of the maximum power point: $\mathrm{d} P / \mathrm{d} V<$ 0 . Such an arrangement is designed to accommodate the usage of a single solar charge controller, MPPT Victron $150 \mathrm{~A}$, which its function is to adsorbing all the energy from every single panel. In conclusion, this PV Panel will produce power up to $1.2 \mathrm{kWh}$, since this electrical boat system works in $48 \mathrm{~V}$ system. Therefore maximum capacity produces by the PV is:

$\mathrm{Wp} \max ($ Total $) /$ working voltage $=1040 \mathrm{Wh} / 48 \mathrm{~V}=21.667 \mathrm{~A}$

This amount of energy will be transferred into battery pack, or when the main propulsion system works in a condition that not exceed maximum charging current from PV Panel, then all the energy from PV will be directly used for the propulsion without taking energy from the battery. However, there is another way to improve the amount of energy adsorbed, by installing every single panel with its own MPPT Solar charge controller. This arrangement will lead to better efficiency because if power drop occurs to a panel, it will not disturb whole system charging activity, so that power drop only occurs at that drooping panel.

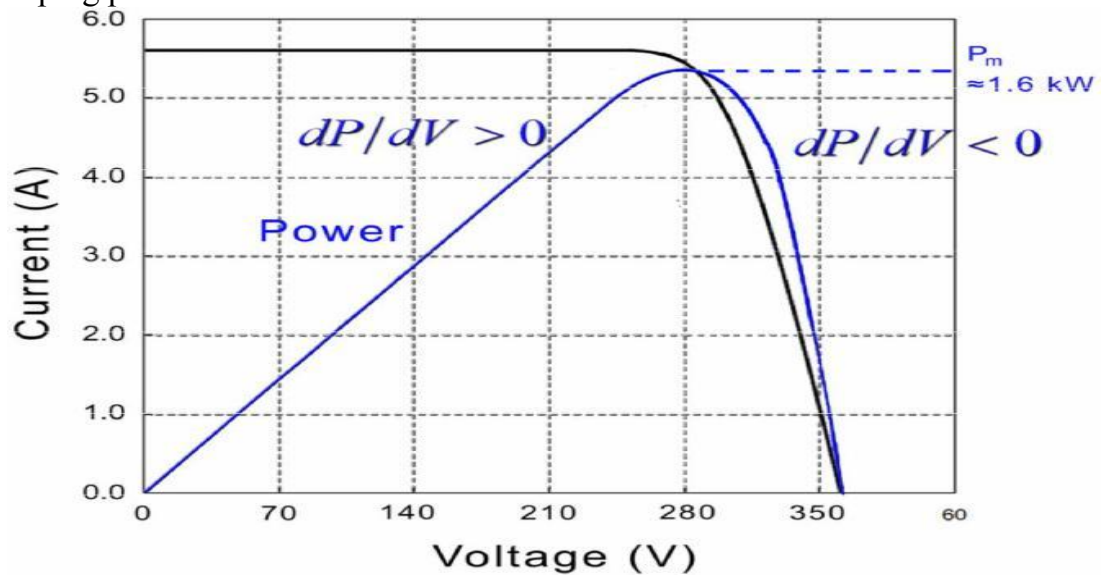

Fig. 3 Output characteristic curve of photovoltaic array strings 


\subsection{Boat performance}

There are several parameters that need to be shown in designing a boat [7]. In this part of the paper will be showing the service speed of the boat, maximum speed, longest traveling range of the boat. With every technical specification and estimated electrical load provided, then the vessel performance can be determined. The method that will be taken to determine consist of:

(i) Identify boat dimension, specification, weight distribution, and build its software model for further test. Also input of environmental condition during sailing, such as water current, solar radiation absorption (assumed $100 \%$ solar radiation absorbed) and other environmental condition that might be considered bothering boat sailing performance.

(ii) Run maxsurf resistance analysis software to identify its power vs. speed performance.

(iii) With power vs. speed figure acquired, then proceed to identify the amount of energy needed to supply with throttle percentage variation. Assuming $100 \%$ is maximum power given from the electric motor.

(iv) Identify boat service speed, maximum speed, and maximum sailing range with each designed speed.

\subsection{Performance test}

In order to get an accurate result of electrical system integrated telemetry system should be installed to record and analyze boat performance, including its energy management system [8]. This system will be covering real-time data from PV panel input (energy generation) until electric propulsion consumption while giving the skipper important information, mostly about remaining energy left and suggestion on a boat cruising speed in order to reach targeted destination. However, in this paper, this system is not yet implemented, as this system will be the next agenda to be taken as the continuation of this research.

\section{Results and discussion}

\subsection{Power Management System (PMS)}

The PMS is used for the right managing of the energy aboard together with monitoring all electrical activity for the boat system [9]. This management system is intended to provide the pilot with sufficient information of real-time battery capacity, with this proper information pilot would be able to determine his sailing preference based on weather condition and amount of energy left.

The system uses a storage device (battery bank) for balancing the mismatch between the available energy by the photovoltaic array and power required by motors and boat instruments. Both the powers that flow in and out of the storage device have to be designed accurately and controlled for a global energy management strategy. Such condition is designed since the lithium-ion batteries decrease the storage capacity with aging, is not possible for the captain to know the instant energy available for the navigation, by measuring the output voltage of the battery. Figure 4 shows the setup of a solar-electric boat. 


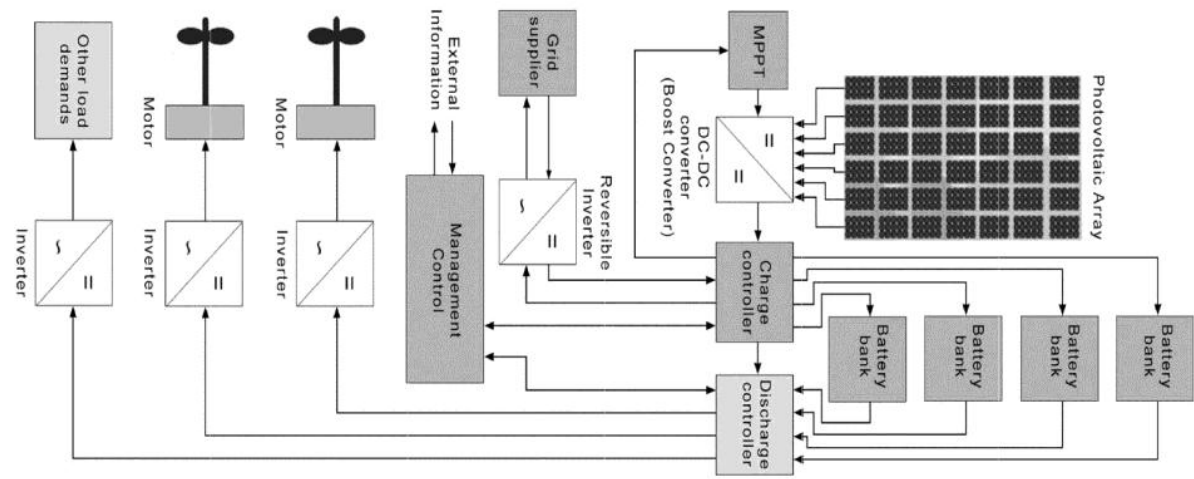

Fig. 4 Topology of a solar boat

In order to provide safety and reliable navigation, it is necessary for boat designer to design boat system that gives the pilot the real autonomy of navigation [10], which means to know the real energy storage within the battery banks. Monitoring, controlling, and preventing become an integral part of every electrical system. The proposed system to support such requirement normally will be composed by a photovoltaic array, one battery banks, a boost converter, a reversible inverter, three inverters, a charge control, a discharge control, and a computer to manage the energy flows (energy management controller).

The maximum current needed for the system to run the motor is about $89.5 \mathrm{~A}$. This current can be supplied by a single battery bank for less than $30 \mathrm{~min}$; it is assumed that pilot gave $100 \%$ throttle on the boat propulsion system. However, during cruising speed, the maximum current is $22 \mathrm{~A}$; this amount of current can be provided from battery bank for more than $1 \mathrm{~h}$ and $15 \mathrm{~min}$. This custom made battery pack can be fully discharged without damage, with protection system / cut-off system that will work when battery voltage reaches below $33 \mathrm{~V}$. This bottom limit can be modified from the Battery Management System. Figure 5 shows the schematic diagram of the proposed electrical system.

\subsection{Control management system}

The principal assignment of the control management system is to determine the real available energy for the navigation and to furnish information on the boat autonomy. To realize this assignment, the system preserves information of the flows of energy and manages the complete discharge/charge of the battery banks.

Every performance data of boat electrical devices will be monitored using the control management system. In advance, the control management will provide the pilot with remaining energy left and possible distance to travel with real-time battery capacity. The control management system should be able to prevent every possible electrical failure in the system. The computer of control management will be programmed to identify a potential threat to the electrical system; this computer will also program with prevention act or at least provide the pilot with sufficient data analysis about an indication of system failure. Meanwhile, this data will be recorded in the boat internal memory or shared to an onshore central computer that assigned to monitor boat activity. If this management control works normally as it was designed, it may be able to provide a bigger safety factor to the operational of the boat. 


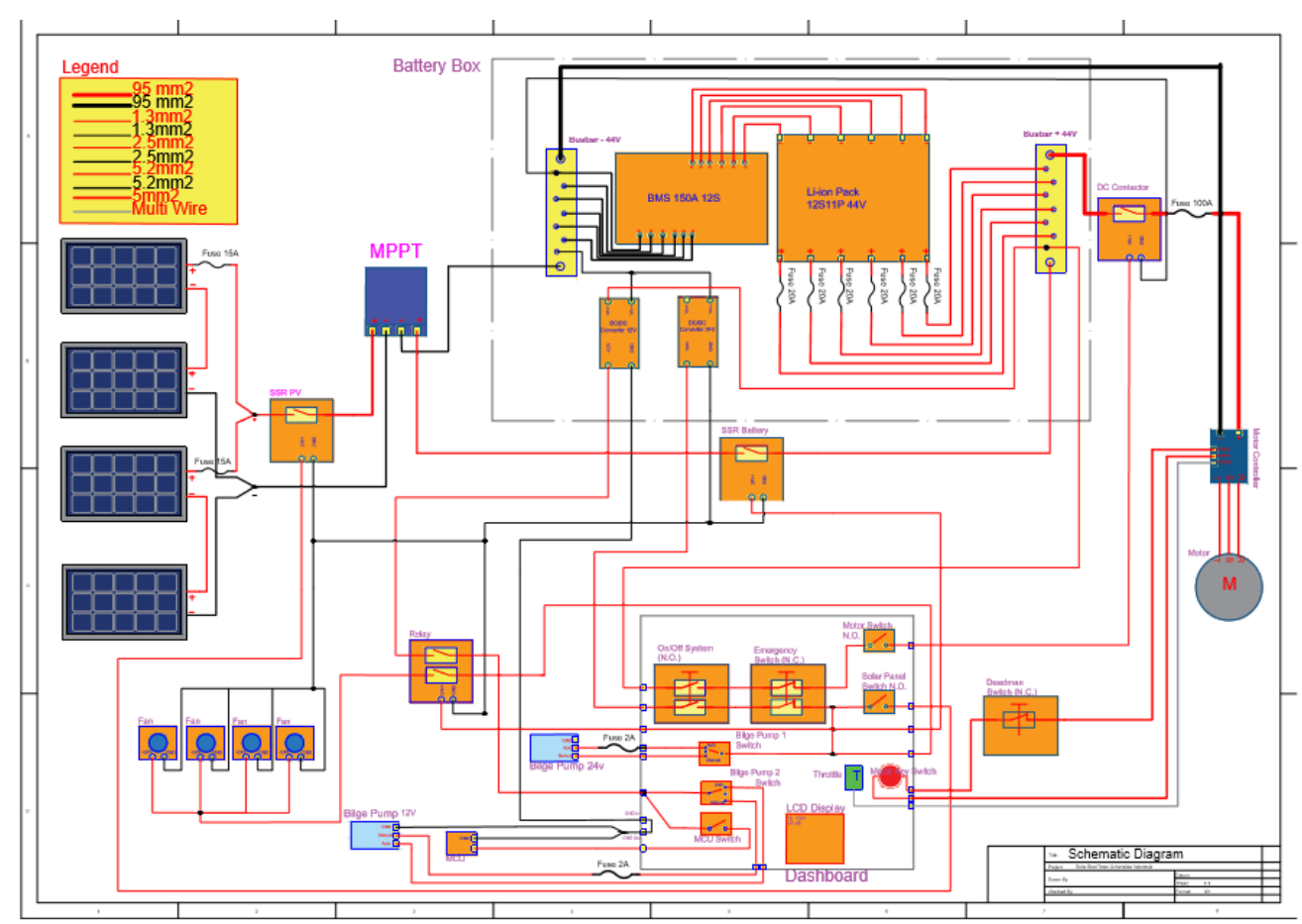

Fig. 5 Electrical schematic diagrams

\subsection{Service speed, maximum speed, and sailing range}

The result of software analysis on boat resistance have given us a prediction of this boat power vs. speed figure, as shown below:

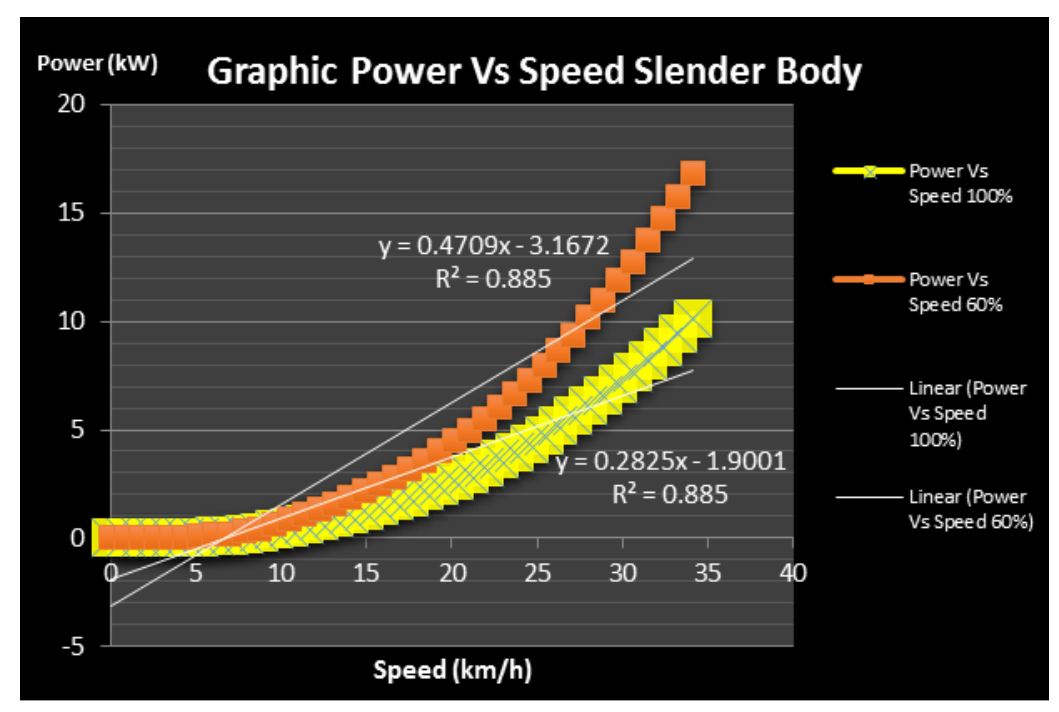

Fig. 6 Power vs. speed maxsurf resistance method slender body 
The figure above is used to identify how much energy consumed or electrical current needed to be supplied to the motor with a variation of throttle percentage [11]. As shown below are the processed data using the figure above:

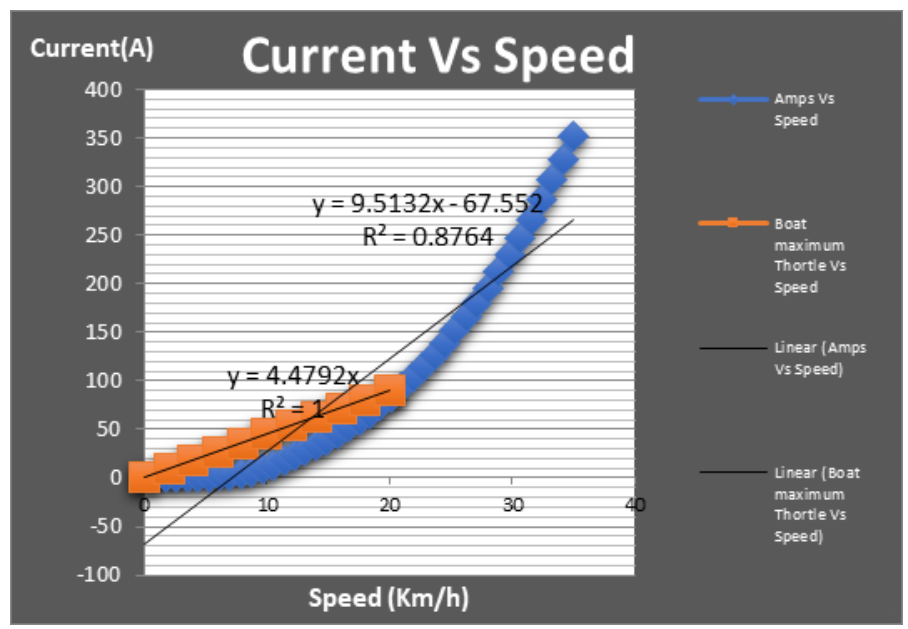

Fig. 7 Current (A) vs. speed

Table 3 Throttle variation

\begin{tabular}{|c|c|c|c|}
\hline Throttle percentage (\%) & Current (A) & Power (kW) & Speed $\left(\mathrm{km} \mathrm{h}^{-1}\right)$ \\
\hline 100 & 89.58 & 4300 & 20.67 \\
\hline 90 & 80.63 & 3870 & 19.83 \\
\hline 80 & 71.67 & 3440 & 18.93 \\
\hline 75 & 67.19 & 3225 & 18.44 \\
\hline 70 & 62.71 & 3010 & 17.96 \\
\hline 60 & 53.75 & 2580 & 16.88 \\
\hline 50 & 44.79 & 2150 & 15.71 \\
\hline 40 & 35.83 & 1720 & 14.39 \\
\hline 30 & 26.87 & 1290 & 12.96 \\
\hline 25 & 22.39 & 1075 & 12.18 \\
\hline 20 & 17.92 & 860 & 11.42 \\
\hline 10 & 8.96 & 430 & 9.58 \\
\hline
\end{tabular}

The result is shown in Figure 7 and Table 3 gives information about how much electrical current needed to be provided on each selection of throttle percentage. Meanwhile we also acquire estimated speed from each throttle percentage. Furthermore, this data will be used to investigate service speed, maximum speed, and sailing range. In order to produce such information, certain technical and limitation should be inputted into the calculation, such as PV Input and battery depth of discharge. 
Table 4 Energy consumption calculation

\begin{tabular}{|c|c|c|c|c|c|}
\hline \multirow{2}{*}{$\begin{array}{c}\text { Speed }\left(\mathrm{km} \mathrm{h}^{-1}\right) \\
{[1]}\end{array}$} & $\begin{array}{c}\text { Input } \\
\text { current } \\
{[2]} \\
\end{array}$ & $\begin{array}{c}\text { Battery } \\
\text { capacity } \\
{[3]} \\
\end{array}$ & \multirow{2}{*}{$\begin{array}{c}\text { Output } \\
\text { current (to } \\
\text { motor) (A) } \\
{[4]}\end{array}$} & \multirow{2}{*}{$\begin{array}{c}\text { Throttle } \\
\text { percentage (\%) } \\
\text { [5] }\end{array}$} & \multirow{2}{*}{$\begin{array}{c}\text { Battery } \\
\text { load (A) } \\
{[6]}\end{array}$} \\
\hline & $\begin{array}{l}\text { PV panel } \\
\text { (A) }\end{array}$ & $\begin{array}{c}\text { Battery (80 } \\
\text { \%) (Ah) }\end{array}$ & & & \\
\hline 20.67 (max) & 21.67 & 26.4 & 89.58 & 100 & 67.92 \\
\hline 19.83 & 21.67 & 26.4 & 80.63 & 90 & 58.96 \\
\hline 18.93 & 21.67 & 26.4 & 71.67 & 80 & 49.99 \\
\hline 18.44 & 21.67 & 26.4 & 67.19 & 75 & 45.52 \\
\hline 17.96 & 21.67 & 26.4 & 62.71 & 70 & 41.04 \\
\hline 16.88 & 21.67 & 26.4 & 53.75 & 60 & 32.08 \\
\hline 15.71 & 21.67 & 26.4 & 44.79 & 50 & 23.13 \\
\hline 14.39 & 21.67 & 26.4 & 35.83 & 40 & 14.17 \\
\hline 12.96 (normal) & 21.67 & 26.4 & 26.88 & 30 & 5.21 \\
\hline 12.18 & 21.67 & 26.4 & 22.395 & 25 & 0.73 \\
\hline 11.42 & 21.67 & 26.4 & 17.92 & 20 & -3.75 \\
\hline 9.58 & 21.67 & 26.4 & 8.96 & 10 & -12.71 \\
\hline
\end{tabular}

Table 5 Energy consumption calculation

\begin{tabular}{|c|c|c|c|}
\hline \multicolumn{2}{|c|}{$\begin{array}{c}\text { Battery draining time until } \mathbf{2 0} \text { \% } \\
\text { [7] }\end{array}$} & Sailing range $\mathbf{( S}=\mathbf{V} \times \mathbf{t}) \mathbf{( k m )}$ & \multirow{2}{*}{ Remaining Range } \\
\hline h & $\mathbf{m i n}$ & & \\
\hline 0.39 (max speed) & $23 \min 32 \mathrm{~s}$ & 8.03 & 51.97 \\
\hline 0.45 & $27 \min 26 \mathrm{~s}$ & 8.88 & 51.12 \\
\hline 0.53 & $32 \min 8 \mathrm{~s}$ & 10.00 & 50.00 \\
\hline 0.58 & $35 \min 19 \mathrm{~s}$ & 10.69 & 49.31 \\
\hline 0.64 & $38 \min 59 \mathrm{~s}$ & 11.55 & 48.45 \\
\hline 0.82 & $49 \min 37 \mathrm{~s}$ & 13.89 & 46.11 \\
\hline 1.14 & $1 \mathrm{~h} 8 \min 27 \mathrm{~s}$ & 17.93 & 42.07 \\
\hline 1.86 & $1 \mathrm{~h} 51 \min 12 \mathrm{~s}$ & 26.82 & 33.18 \\
\hline 5.07 (normal speed) & $5 \mathrm{~h} 4 \min 2 \mathrm{~s}$ & 65.69 & -5.69 \\
\hline 36.21 & $36 \mathrm{~h} 12 \min$ & $>60 \mathrm{~km}$ & $>60 \mathrm{~km}$ \\
\hline Battery Charging & Battery Charging & More than $60 \mathrm{~km}$ & $>60 \mathrm{~km}$ \\
\hline Battery Charging & Battery Charging & More than $60 \mathrm{~km}$ & $>60 \mathrm{~km}$ \\
\hline
\end{tabular}

As shown above, the boat could travel with maximum speed at $20.67 \mathrm{~km} \mathrm{~h}^{-1}$ with $100 \%$ throttle opening. During this state of speed, the battery will last for $23 \mathrm{~min}$ and $32 \mathrm{~s}$ before reaching its D.o.D limit. Meanwhile, the sailing range produced is $8.03 \mathrm{~km}$.

The information of boat service speed can be varied by how long sailing range needed to be complete in one sailing condition, if the boat designed to sail up to $60 \mathrm{~km}$, then it recommended sailing with a constant $30 \%$ throttle opening that gives $12.96 \mathrm{~km} \mathrm{~h}^{-1}$ of sailing speed and sailing range up to $65 \mathrm{~km}$ with $5 \mathrm{~h} 4 \mathrm{~min}$ and $2 \mathrm{~s}$ of sailing duration. Other sailing speed option can be decided by how long the boat will travel, then proceed to look at the table above for which sailing speed is best for the desired sailing range. 


\section{Conclusion}

The design of a Solar-Electric Boat for personal use as tourist's recreational vessel along the coast, in the rivers, in the lakes has been presented in detail. With this system, it is possible to replace the common type of personal water recreational vehicle. In advance, this design can be a preference for fuel engine to electrical propulsion conversion of a passenger vessel, by realizing a loss in power, and without changing the weight and the dimension of the boat. In an aspect of new construction, the construction of the boat should be able to handle the boat load design. By optimizing the use of the material in accordance with the boatload design, will provide a significant weight reduction and making it more efficient.

This research is funded by PITTA project contract No.841/UN2.R3.1/HKP.05.00/2017, Initiated by Directorate of Research and Community Engagement Universitas Indonesia. Thanks are delivered to Department of Mechanical Engineering - Universitas Indonesia, Naval Architect program study, also Solar Boat Team Universitas Indonesia 2016 who had raced in the Netherland that provide us with significant data and experienced to work on this research, and for every party that supports the development of this research.

\section{References}

1. T. Rifai, E. Solheim, and P. Espinosa. Let's Make All Tourism Green and Clean, United Nations Environment Programme (2017).

https://www.unenvironment.org/news-and-stories/blog-post/lets-make-all-tourismgreen-and-clean [Accessed 18 March 2018].

2. A. Collins. 'MS turanor planetsolar' is the world's largest solar-powered boat. Designboom. (2013). https://www.designboom.com/technology/ms-turanorplanetsolar-worlds-largest-solar-powered-boat/ [Accessed 18 March 2018].

3. J. Melot. Azura Marine Earth. (2016). https://www.awesomefoundation.org/en/projects/71911-azura-marine-earth [Accessed 18 November 2017].

4. C. Thamson. SoelCat 12 Electric Yacht. Business Insider (2017). https://www.businessinsider.com/soelcat-12-electric-yacht-solar-powered-2017-5/ [Accessed 18 March 2018].

5. A. Kurniawan. A Review of Solar-Powered Boat Development. Journal for Technology and Science, 27,1:1-8(2016). http://www.iptek.its.ac.id/index.php/jts/article/view/761 [Accessed 18 March 2018].

6. S.B.T.U. Indonesia, Project. [Online] from http://solarboat.ui.ac.id/projects/ (2016). [Accessed 18 May 2017].

7. A. Salem, I.S. Seddiek. Techno-Economic Approach To Solar Energy Systems Onboard Marine Vehicles, Polish Maritime Research, 23:64-71(2016). https://www.degruyter.com/downloadpdf/j/pomr.2016.23.issue-3/pomr-20160033/pomr-2016-0033.xml

8. S. Tukaram, S.R. Uttam, R.S. Shivaji, N.R. Ankush, K.M. Kare, Design And Fabrication Of A Solar Boat, International Journal of Innovation in Engineering Research and Technology, 3,1:1-4(2016). https://www.ijiert.org/download file?file $=1453195178$ Volume $\% 203 \% 20$ Issue $\% 201 . p d f$

9. K. Mahmud, S. Morsalin, I. Khan, Design and Fabrication of an Automated Solar Boat, International Journal of Advanced Science and Technology,64:31-42(2014). 
https://www.researchgate.net/publication/284403723_Design_and_Fabrication_of an Automated_Solar_Boat/citation/download

10. G.S. Spagnolo, D. Papalillo, A. Martocchia, G. Makary. Solar-electric Boat Journal of Transportation Technologies, 2,2:144-149(2012).

https://www.scirp.org/journal/PaperInforCitation.aspx?PaperID=18587

11. T. Gorter. Design considerations of a solar racing boat: Propeller design parameters as a result of $P V$ system power. The 7th International Conference On Applied EnergyICAE2015, (Leeuwarden, 2015). Energy Procedia 75:1901-1906(2015). https://cyberleninka.org/article/n/1146093.pdf 